\title{
SIMULASI NUMERIK GELOMBANG (SPECTRAL WAVES) DAN BENCANA ROB MENGGUNAKAN FLEXIBLE MESH DAN DATA ELEVATION MODEL DI PERAIRAN KECAMATAN SAYUNG, DEMAK
}

\section{NUMERICAL SIMULATION OF SPECTRAL WAVES AND ROB DISASTER USING FLEXIBLE MESH AND DATA ELEVATION MODEL IN WATERS OF SAYUNG DISTRICT, DEMAK}

\author{
Koko Ondara*, Ulung Jantama Wisha
}

Loka Penelitian Sumber Daya dan Kerentanan Pesisir, Balai Penelitian dan Pengembangan Kementerian Kelautan dan Perikanan

JL. Raya Padang-Painan KM. 16, Teluk Bungus Padang - Sumatera Barat, 25245 Indonesia

*Corresponding author e-mail: koko_ondara@kkp.go.id

Submitted: 2 September 2016 / Revised: 29 Oktober 2016 / Accepted: 30 Oktober 2016

DOI: $h$ ttp://dx.doi.org/10.21107/jk.v9i2.1694

\begin{abstract}
Coastline area in subdistrict Sayung is an abrasion area in Demak which has the worst affected of sea level rise. The purpose of this study to determine the wave dynamics that occur in any tidal conditions and their effects on tidal flood and overtopping happened. The research method is quantitative descriptive using numerical equations, MIKE 21 simulation and ArcGIS elevation models. Hs 2016 on a tide 0.015 to $0.359 \mathrm{~m}$ and in full retroactively from 0.009 to $0.358 \mathrm{~m}$. The results of data processing showed no drastic difference puddle that occur at high tide and low tide. The area of tidal inundation model in 2016 amounted to $7200.36 \mathrm{Ha}$. To the farthest distance from the shoreline tidal inundation in 2016 with a distance of $10826.7 \mathrm{~m}$. There are an increasing wave heights including a full moon and neap tide conditions each year. This shows abrasion occurs is influenced by the piling up of waves that occur continuously. Sea level rise that occurs annually is inversely proportional to the resulting inundation area, so we need a preventive action on the processes of governance of coastal areas.
\end{abstract}

Keywords: elevation models, waves, numerical models, tidal flood, Sayung

\section{ABSTRAK}

Pesisir Kecamatan Sayung merupakan wilayah abrasi di Kabupaten Demak yang terkena dampak paling parah dari kenaikan muka air laut. Tujuan penelitian ini untuk mengetahui dinamika gelombang yang terjadi pada setiap kondisi pasang surut dan pengaruhnya terhadap rob serta overtopping yang terjadi. Metode penelitian adalah deskriptif kuantitatif menggunakan persamaan numerik, simulasi MIKE 21 dan model elevasi ArcGis. Hs tahun 2016 pada pasang purnama 0,015 - 0,359 m dan pada surut purnama 0,009 - 0,358 m. Hasil pengolahan data menunjukkan ada perbedaan yang drastis genangan yang terjadi pada saat pasang dan surut. Luas area model genangan rob pada tahun 2016 sebesar 7200,36 Ha. Untuk jarak terjauh genangan rob dari garis pantai pada tahun 2016 sejauh 10826,7 m. Terdapat peningkatan tinggi gelombang termasuk kondisi pasut purnama dan perbani tiap tahunnya. Hal ini menunjukkan abrasi terjadi di pengaruhi oleh kikisan gelombang yang terjadi secara terus-menerus. Kenaikan muka air laut yang terjadi setiap tahunnya berbanding terbalik dengan luas genangan yang dihasilkan, sehingga perlu dilakukan tindakan yang preventif pada proses tata kelola ruang pesisir.

Kata Kunci: model elevasi, gelombang, model numerik, banjir rob, Sayung 


\section{PENDAHULUAN}

Abrasi atau erosi pantai disebabkan oleh adanya angkutan sedimen menyusur pantai sehingga menyebabkan berpindah sedimen dari satu tempat ke tempat lainnya (Triatmodjo, 2012). Kabupaten Demak merupakan salah satu wilayah pesisir yang terletak di pesisir utara Pulau Jawa yang rawan terhadap kenaikan muka air laut, banjir pasang, abrasi dan akresi karena berada pada wilayah yang bertopografi yang rendah. Sayung merupakan salah satu kecamatan di Kabupaten Demak yang mengalami banjir pasang paling parah diantara kecamatan yang lain. Daerah pesisir di Kecamatan Sayung yang terkena banjir rob pada ketinggian 0,25m adalah Desa Sriwulan, Desa Surodadi, Desa Bedono dan Desa Timbulsloko (Desmawan, 2014).

Banjir pasang menggenangi perumahan penduduk serta merusak penggunaan lahan perumahan, lahan sawah, lahan tambak, serta fasilitas umum seperti jalan, saluran drainase, dan air bersih. Perubahan garis pantai dan sedimentasi, disebabkan oleh faktor alam dan/atau faktor manusia. Pada tahun 1990-an, sebagian besar masyarakat penduduk di Kecamatan Sayung bermata pencaharian sebagai nelayan, petambak,

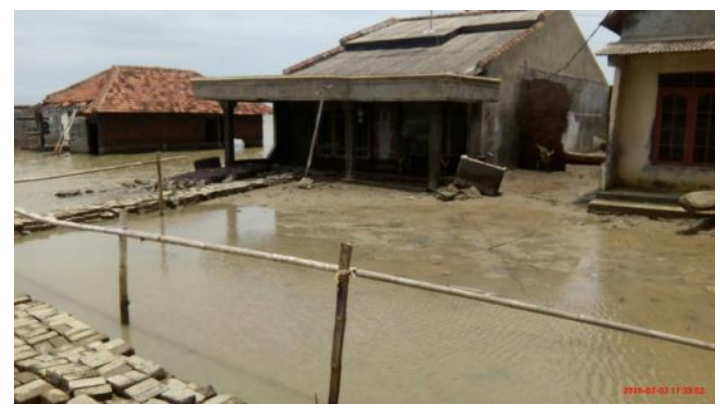

dan petani. Dengan adanya hutan mangrove, wilayah pesisir yang mereka tempati aman dari abrasi dan pasang. Bagi petambak, terutama petambak bandeng, hutan mangrove menjadi habitat dan pakan alami ikan yang mereka pelihara. Akan tetapi keadaan tersebut mulai berubah sejak adanya konversi lahan mangrove, tambak bandeng, dan sawah menjadi lahan tambak udang windu. Selain itu, beberapa tambak di kecamatan Sayung masih dapat dikembangkan dengan cara-cara tertentu tantap merusak keseimbangan alam (Arif et al., 2006)

Dampak dari konversi tersebut adalah menyebabkan perubahan garis pantai dan air laut masuk ke daratan. Bahan-bahan kimia yang digunakan untuk pakan udang juga merusak dan menurunkan kualitas tambak. Penghasilan nelayan menjadi turun karena menurunnya hutan mangrove. Petani juga mengalami kerugian karena lahan menjadi tidak subur sehingga tidak bisa digunakan untuk bertanam. Ekosistem hutan mangrove yang sejatinya merupakan penahan gelombang dan angin serta arus laut menjadi hilang sehingga tidak ada lagi penghalang masuknya air laut ke daratan (Manumono, 2008).

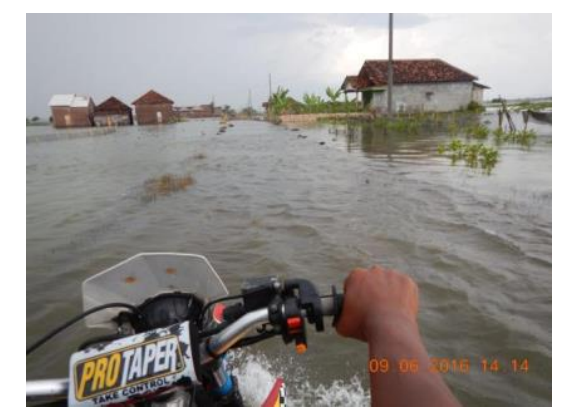

Gambar 1. Pengamatan efek dari bencana Rob dan Abrasi yang terjadi di Pesisir Kab. Demak

Pemunduran garis pantai yang terjadi di sepanjang pantai Kabupaten Demak, khususnya Kecamatan Sayung telah menyebabkan kerusakan dan menimbulkan dampak baik secara sosial, ekonomi maupun lingkungan. Mundurnya garis pantai ini menyebabkan permukiman penduduk semakin dekat dengan pantai, bahkan telah menyebabkan hilangnya permukiman di Dusun Tambaksari, Desa Bedono, Kecamatan Sayung (Pratomoatmojo dan Sianturi, 2011). Pengaruh pasang surut laut dalam dinamika pantai tidak terlalu besar namun juga tidak dapat diabaikan. Pergerakan pasang surut merupakan gerak naik dan turunnya muka air laut secara berirama. Pada saat pasut terjadi akan menimbulkan arus pasut meski tidak terlalu besar jika dibandingkan dengan arus yang terjadi di laut lepas. Namun arus pasut ini juga dapat menjadi media transport bagi sedimen-sedimen berukuran kecil seperti pasir halus dan lempung seperti yang biasa ditemui di muara-muara sungai (Wibowo, 2012). 
Perubahan permukiman yang hilang akibat abrasi dan inundasi di Pesisir Kecamatan Sayung Kabupaten Demak Tahun 2003 2013 sebanyak 221 unit permukiman hilang dari Pesisir Kecamatan Sayung selama kurun waktu 10 tahun dengan karakteristik permukiman kumuh di Pesisir Kecamatan Sayung adalah dinding bangunan, lantai rumah, jalan, serta sarana dan prasarana yang rusak dan menjadi kumuh karena abrasi dan inundasi. Persebaran permukiman kumuh di Pesisir Kecamatan Sayung menyebar di seluruh dusun yang terdapat di permukiman berbatasan langsung dengan laut dan bantaran sungai - sungai disekitar desa. Sebanyak 83 permukiman menjadi kumuh karena abrasi dan 2.036 permukiman kumuh karena inundasi (Asiyah et al., 2015). Secara umum jika di wilayah pantai Indonesia mengalami kenaikan muka laut 1 $\mathrm{m}$ dapat mengakibatkan mundurnya garis pantai sejauh $50 \mathrm{~m}$ dan penggenangan di wilayah pantai (Diposaptono, 2009). Bahkan banjir rob yang terjadi pada bulan juni Ialu telah menyebabkan jalan pantura macet panjang sepanjang $3 \mathrm{~km}$ (detik.com, 2016). Perubahan garis pantai yang signifikan di Kecamatan Wedung, Kabupaten Demak dengan nilai akresi maksimum sebesar 233,994 meter dan abrasi maksimum sebesar 141,037 meter dari tahun 2012 hingga 2015 (Istiqomah et al., 2016). Salah satu alternatif untuk perlindungan Pantai Sayung Demak yaitu bangunan pelindung kombinasi revetment dan breakwater (Hakim et al., 2014).

Data/informasi dan model yang didapat dari penelitian ini dapat dijadikan sebagai dasar dan dapat dikembangkan lebih jauh untuk memahami tidak hanya fenomena abrasi dan yang tertadi di Kecamatan Sayung tetapi juga upaya - upaya dan pengambilan kebijakan terkait penanganan yang akan terus terjadi walaupun upaya perbaikan telah dilaksanakan.

\section{MATERI DAN METODE}

Penelitian ini dilaksanakan pada bulan Maret hingga Juni 2016 di perairan kecamatan Sayung yang secara administrasi berada di empat desa yang berada di daerah Pesisir. Keempat desa tersebut adalah Desa Sriwulan, Desa Bedono, Desa Timbulsloko, dan Desa Surodadi. Alasan dipilihnya empat desa tersebut adalah karena berbatasan langsung dengan pesisir dan mengalami perubahan permukiman serta penurunan kualitas permukiman akibat abrasi dan inundasi. Data primer yang diambil secara in situ adalah besar dan arah kecepatan arus tiap kedalaman 1,5 meter dan data pasang surut menggunakan Accoustic Doppler Curent Profiller yang diletakkan didasar perairan Kec. Sayung, Demak. Data kedalaman perairan dilakukan menggunakan EchoSounder Multi Beam yang diletakkan di atas kapal.
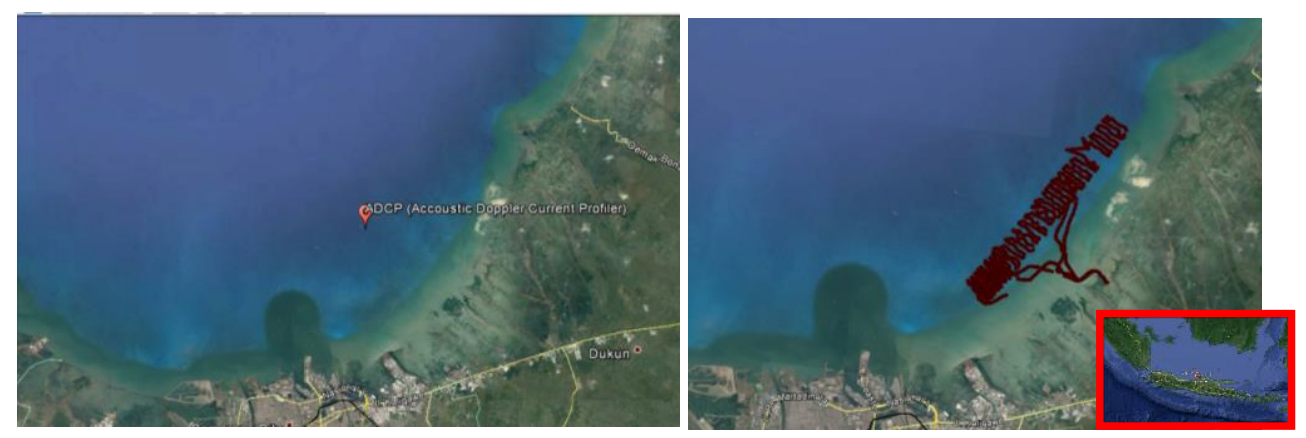

Gambar 2. Lokasi Pemasangan ADCP dan Survei Batimetri di Perairan Kec. Sayung, Kab. Demak

Metode penelitian yang digunakan adalah deskriptif kuantitatif dengan terlebih dahulu menentukan timeline dan rundown penelitian, pengambilan data di lapangan, pengambilan serta pengujian sampel.
Analisa yang digunakan dalam penelitian ini adalah analisa transformasi gelombang, simulasi numerik hidrodinamika dan analisa rob. 


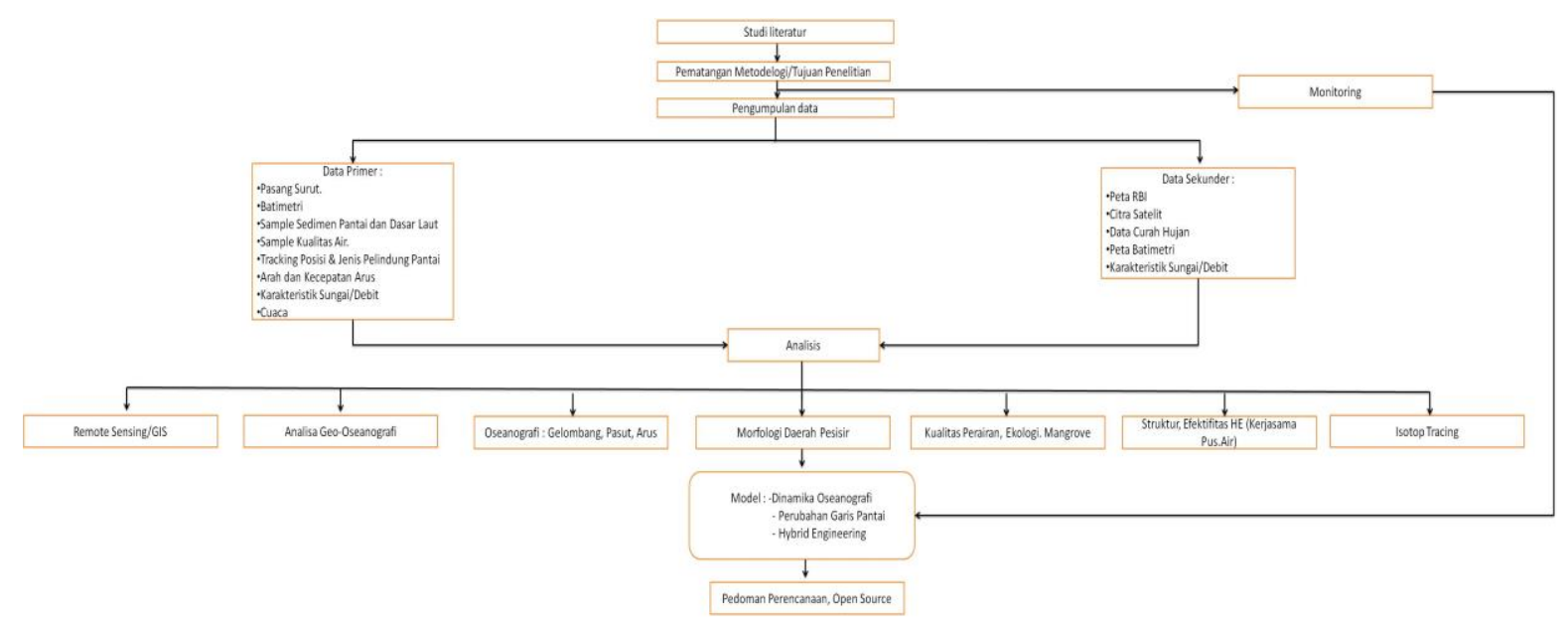

Gambar 3. Diagram alur penelitian

Fetch efektif digunakan dalam peramalam gelombang untuk mengetahui tinggi, periode dan durasi gelombang. Perhitungan fetch dilakukan terlebih dahulu dengan menentukan garis arah angin utama sebagai central radial dengan menggunakan peta daerah Perairan Sayung, Ialu dibuat sudut dari central radial kerah kanan dan kiri garis fetch dengan interval 22,50. Fetch diukur sampai menyentuh daratan atau batas akhir peta kemudian kalikan dengan skala peta. Data angin yang akan digunakan untuk peramalan tinggi dan perioda gelombang harus dikoreksi terhadap elevasi, stabilitas, efek lokasi dan koefisien seret untuk mendapatkan wind stress factor atau faktor tenaga angin (Coastal Hydrolic Laboratory, 2012). Untuk menghitung wind stress factor $\left(\mathrm{U}_{\mathrm{A}}\right)$ digunakan persamaan:

$$
U_{A}=0.71 x\left(R_{L} x U_{L}\right)^{1.23}
$$

dengan $U_{L}$ adalah kecepatan angin hasil pengukuran dan $R_{L}$ adalah hubungan antara angin diatas laut dan angin di daratan terdekat (Triatmodjo, 2012).

Dalam penentuan tinggi dan periode gelombang maksimum yang terjadi berdasarkan perubahan kedalaman, dibuat hubungan antara tinggi gelombang maksimum dan periode gelombang maksimum yang telah dihitung dengan metode hindcasting untuk mendapatkan persamaan dari grafik hubungan. Kemudian persamaan yang didapatkan dari grafik hubungan tersebut digunakan untung menghitung periode gelombang pada laut dalam yang akan digunakan untuk menghitung nilai koefisien refraksi. Kemudian menghitung nilai koefisien shoaling untuk mendapatkan nilai tinggi gelombang yang baru. Perhitungan dilakukan dengan menggunakan grafik yang tersedia yaitu grafik yang menyatakan hubungan antara $H^{\prime}{ }_{0} / g T^{2}$ dan $\mathrm{Hb} / \mathrm{H}_{0}{ }_{0}$. Nilai $\mathrm{Hb}$ didapatkan dari hasil plot antara nilai $H_{0}^{\prime} / g T^{2}$ dan kemiringan pantai (Triatmodjo, 2012). Pemodelan dan simulasi pasang surut dan karakteristik arus menggunakan MIKE21 dengan perubahan pola densitas bersifat barotropik (Peterson, 2013)

Dalam analisa citra satelit, data DEM yang digunakan adalah data DEM SRTM $30 \times 30$ hasil perekaman satelit space shuttle "Endeavor" tahun 2000 oleh NASA. Data spasial ini memiliki resolusi spasial $30 \mathrm{~m}$. Data DEM SRTM (Shuttle Radar Tophography Mission) merupakan data digital berformat raster yang memiliki informasi koordinat posisi $(\mathrm{x}, \mathrm{y})$ dan elevasi $(\mathrm{z})$ pada setiap pixelnya atau selnya. Model genangan rob menggunakan formula yang merefleksikan perubahan MSL. Wilayah yang terkena genangan rob diketahui dengan cara memasukkan nilai kenaikan muka air laut. Sedangkan untuk inputan tinggi muka air laut adalah selisih antara HHWL dan MSL. Dalam pembuatan model genangan dilakukan perhitungan dengan menggunakan Raster Calculator pada software ArcGIS 10.0. 


\section{HASIL DAN PEMBAHASAN}

\section{Analisa Transformasi Gelombang}

Hasil perhitungan fetch untuk empat arah mata angin utama di perairan Sayung dapat dilihat pada tabel 1 dibawah ini.

Tabel 1. Perhitungan fetch rerata efektif

\begin{tabular}{rlr}
\hline No & Arah Utama Angin & \multicolumn{1}{c}{ Fetch $(\mathbf{m})$} \\
\hline 1 & Utara & 14715.98 \\
2 & Timur laut & 12739.01 \\
3 & Timur & 6320.98 \\
4 & Tenggara & 00.00 \\
5 & Selatan & 00.00 \\
6 & Barat Daya & 2593.41 .00 \\
7 & Barat & 12429.29 \\
8 & Barat Laut & 17514.90 \\
\hline
\end{tabular}

Grafik pada gambar 4 dapat diketahui bahwa gelombang dominan dan maksimum dari arah Barat laut dan Utara. Hal ini disebabkan karena daerah tersebut merupakan salah satu lokasi terjadinya El Nino Southern Oscillation dan secara topografi tidak ada penghalang untuk arah angin masuk kedalam bagian daratan. Dari tabel juga diketahui bahwa daerah gelombang dari arah timur mempunyai daerah pembangkitan gelombang yang lebih besar.

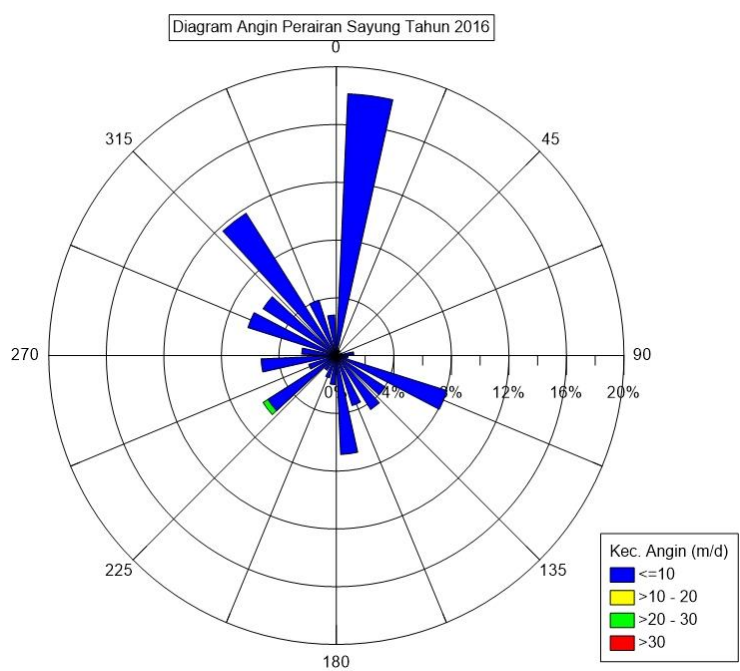

Gambar 4. Arah angin dominan di Perairan Sayung

Data angin yang akan digunakan untuk peramalan tinggi dan perioda gelombang harus dikoreksi terhadap elevasi, stabilitas, efek lokasi dan koefisien seret untuk mendapatkan wind stress factor atau faktor tenaga angin (UA). Data angin yang digunakan adalah data angin maksimum harian yang akan menyebabkan tinggi gelombang maksimum

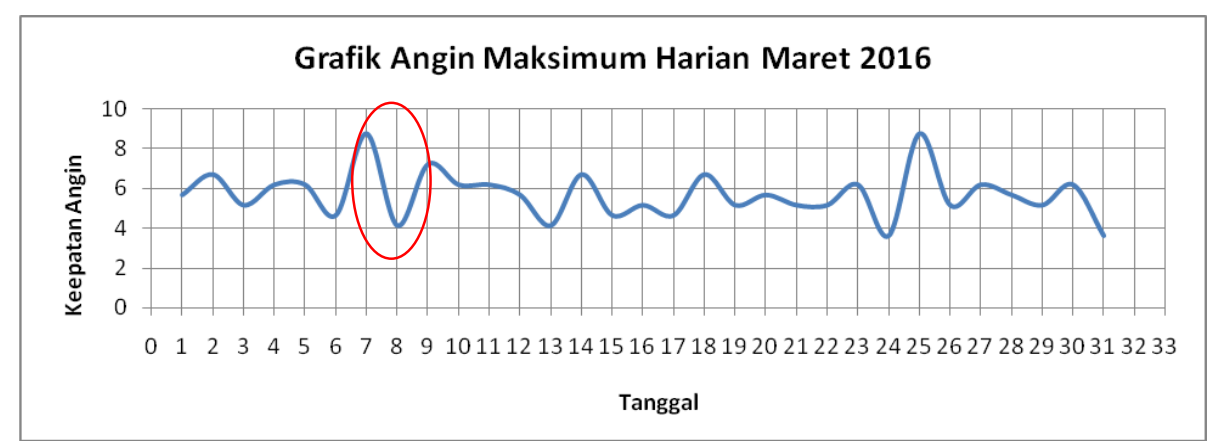

Gambar 5. Grafik angin maksimum harian perhitungan secara numerik

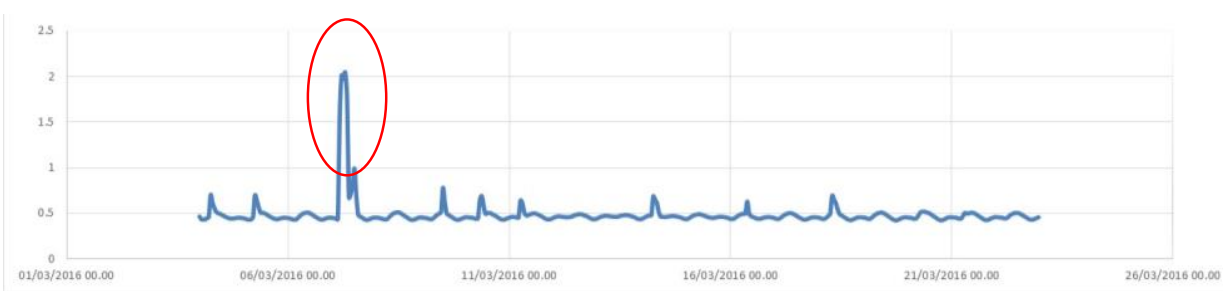

Gambar 6. Grafik tinggi gelombang harian hasil pemodelan 
Terlihat bahwa pada grafik yang terdapat pada gambar 4 dan gambar 5 , nilai angin maksimum terjadi pada tanggal 7 Maret 2016, tinggi gelombang menunjukkan nilai yang maksimum pada waktu yang sama. Hal ini terjadi karena nilai tinggi gelombang yang dipengaruhi oleh besar nya angin permukaan yang terjadi di wilayah perairan

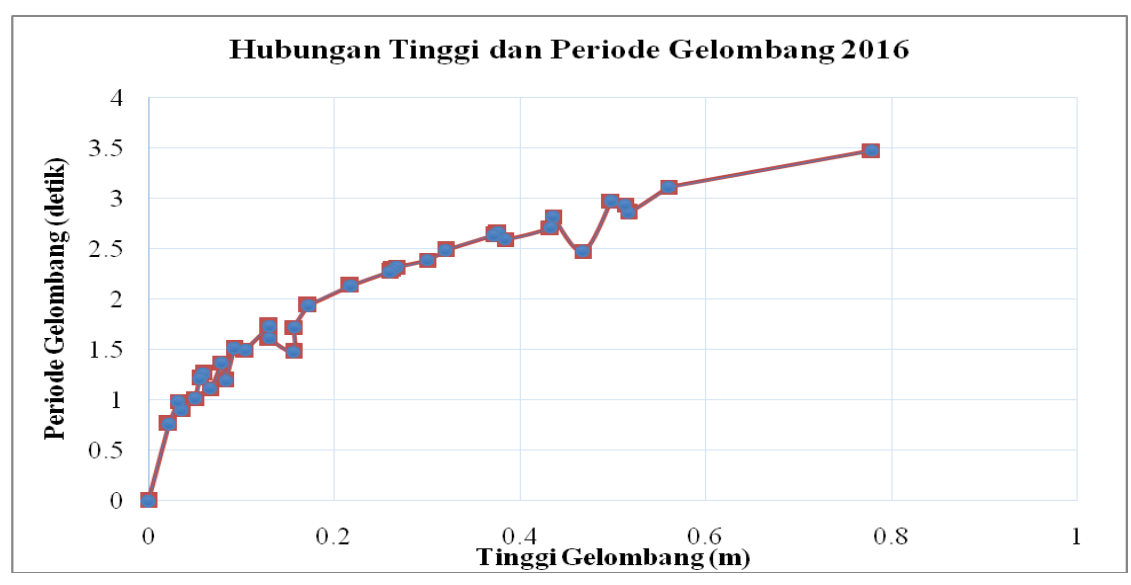

Gambar 7. Grafik hubungan tinggi dengan periode gelombang untuk arah Timur

Berikut ini adalah perhitungan koefisien refreksi untuk delapan penjuru arah mata angin yang terjadi di perairan Kecamatan Sayung

Tabel 2. Koefisien refraksi untuk arah Utara dan Selatan

\begin{tabular}{clcccccc|cccccc}
\hline NO & \multicolumn{1}{c}{ Utara } & \multicolumn{7}{c}{ Selatan } \\
\hline 1 & $\mathrm{z}(\mathrm{m})$ & 10 & 8 & 6 & 4 & 2 & 0.1 & 10 & 8 & 6 & 4 & 2 & 0.1 \\
2 & $\sin \alpha$ & - & - & 0 & 0 & 0 & 0 & - & - & $1.23 \mathrm{E}-16$ & $1.23 \mathrm{E}-16$ & $1.3 \mathrm{E}-16$ & $5.03 \mathrm{E}-17$ \\
3 & $\alpha$ & - & - & 0 & 0 & 0 & 0 & - & - & $7.02 \mathrm{E}-15$ & $7.06 \mathrm{E}-15$ & $7.46 \mathrm{E}-15$ & $2.88 \mathrm{E}-15$ \\
4 & $\mathrm{Kr}$ & - & - & 0.13 & 0.13 & 0.13 & 0.13 & - & - & - & - & - & - \\
\hline
\end{tabular}

Tabel 3. Koefisien refraksi untuk arah Timur laut dan Barat Daya

\begin{tabular}{cccccccc|cccccc}
\hline NO & \multicolumn{7}{c|}{ Timur Laut } & \multicolumn{6}{c}{ Barat Daya } \\
\hline 1 & $\mathrm{z}(\mathrm{m})$ & 10 & 8 & 6 & 4 & 2 & 0.1 & 10 & 8 & 6 & 4 & 2 & 0.1 \\
2 & $\sin \alpha$ & - & - & 0.71 & 0.71 & 0.75 & 0.29 & - & - & -0.67 & -0.67 & -0.71 & -0.27 \\
3 & $\alpha$ & - & - & 45 & 45.3 & 48.7 & 16.9 & - & - & -42.53 & -42.78 & -45.88 & -16.11 \\
4 & $\mathrm{Kr}$ & - & - & 0.14 & 0.19 & 0.69 & & - & - & - & - & 0.21 & 0.12 \\
\hline
\end{tabular}

Tabel 4. Koefisien refraksi untuk arah Timur dan Barat

\begin{tabular}{cccccccc|cccccc}
\hline NO & \multicolumn{7}{c|}{ Timur } & \multicolumn{7}{c}{ Barat } \\
\hline 1 & $\mathrm{z}(\mathrm{m})$ & 10 & 8 & 6 & 4 & 2 & 0.1 & 10 & 8 & 6 & 4 & 2 & 0.1 \\
2 & $\sin \alpha$ & - & - & 1 & 1.01 & 1.06 & 0.41 & - & - & -1.01 & -1.01 & -1.062 & -0.41 \\
3 & $\alpha$ & - & - & - & - & - & 24.3 & - & - & - & - & - & -24.26 \\
4 & $\mathrm{Kr}$ & - & - & - & - & - & - & - & - & - & - & - & 0.16 \\
\hline
\end{tabular}

Tabel 5. Koefisien refraksi untuk arah Tenggara dan Barat

\begin{tabular}{cccccccc|cccccc}
\hline NO & \multicolumn{7}{c|}{ Tenggara } & \multicolumn{6}{c}{ Barat Laut } \\
\hline 1 & $\mathrm{z}(\mathrm{m})$ & 10 & 8 & 6 & 4 & 2 & 0.1 & 10 & 8 & 6 & 4 & 2 & 0.1 \\
2 & $\sin \alpha$ & - & - & 0.71 & 0.71 & 0.75 & 0.29 & - & - & -0.71 & -0.71 & -0.75 & -0.29 \\
3 & $\alpha$ & - & - & 45 & 45.3 & 48.7 & 16.9 & - & - & -45.03 & -45.31 & -48.71 & -16.89 \\
4 & $\mathrm{Kr}$ & - & - & - & - & - & - & - & - & 0.15 & 0.21 & 0.77 & - \\
\hline
\end{tabular}


Tabel 6. Perhitungan koefisien shoaling perairan Kecamatan Sayung

\begin{tabular}{lccrrrr}
\hline $\mathrm{z}(\mathrm{m})$ & 10 & 8 & 6 & 4 & 2 & 0.1 \\
$\mathrm{n}$ & - & - & 0.4871 & 0.4194 & 0.2028 & 0.9258 \\
$\mathrm{Ks}$ & - & - & 1.0129 & 1.089 & 1.5231 & 1.1464 \\
$\mathrm{H}$ & - & - & 0.042 & 0.0451 & 0.0631 & 0.0475 \\
\hline
\end{tabular}

Tabel 7. Perhitungan gelombang pecah perairan Kecamatan Sayung

\begin{tabular}{llrrrrr}
\hline$z(m)$ & 10 & 8 & 6 & 4 & 2 & 0.1 \\
H'o & & & 0.0414 & 0.0414 & 0.0414 & 0.0414 \\
H'o/gt2 & & & 0.0023 & 0.0023 & 0.0023 & 0.0023 \\
\hline
\end{tabular}

Berdasarkan dari tabel 7, diperoleh bawah gelombang pecah pada nilai 0,04 meter dengan kedalaman 6 meter.

\section{Analisa Hidrodinamika}

Berdasarkan data batimetri pengukuran langsung serta pemetaan terhadap wilayah garis pantai, maka diambil 2 kontur potongan profil pantai di Kecamatan Sayung. Kontur merupakan gambaran persamaan kedalaman yang dilihat pada bidang datar.
Pengambilan 2 kontur ini didasarkan pertimbangan bahwa kontur tersebut mewakili nilai rata-rata profil ketinggian yang ada di daerah penelitian. Daerah kontur tersebut juga dianggap sebagai laahan yang stabil dan tidak terlalu banyak mengalami perubahan struktur topografi dan lebih stabil bentuk geomorfologinya. Perubahan kedalaman perairan dari garis pantai secara vertikal dapat dilihat dengan potongan melintang tegak lurus garis pantai yang diambil pada 2 lokasi.

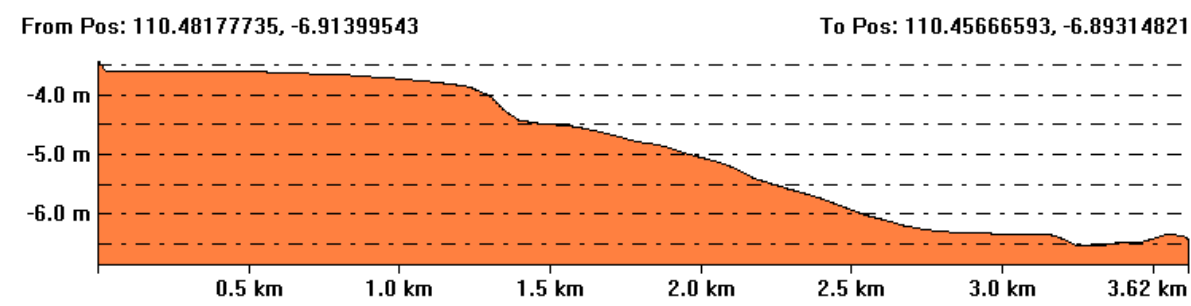

Gambar 8. Profil dan Kemiringan Pantai Lokasi 1

Potongan 1 pada Gambar 8 menunjukkan perubahan kedalaman dimulai pada jarak sejauh $1.4 \mathrm{~km}$ dan perbedaan elevasi terdangkal dengan terdalam adalah $2.5 \mathrm{~m}$ dengan jarak sejauh $3.62 \mathrm{~km}$ termasuk kelas bentuk lahan landai dan sangat landai.

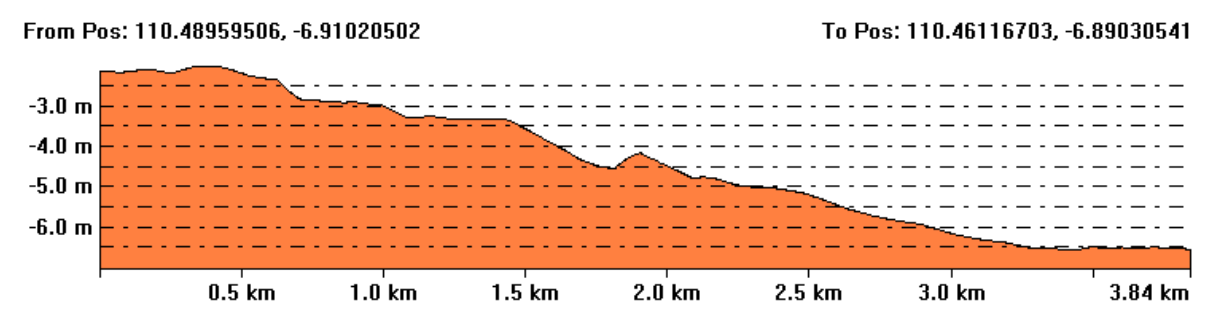

Gambar 9. Profil dan Kemiringan Pantai Lokasi 2

Potongan 2 pada Gambar 9 menunjukkan perubahan kedalaman dimulai pada jarak sejauh $750 \mathrm{~m}$ dan perbedaan elevasi terdangkal dengan terdalam adalah $4.5 \mathrm{~m}$ dengan jarak sejauh 3.84 km termasuk kelas bentuklahan landai dan sangat landai. Hasil simulasi pemodelan numerik hidrodinamika, diperoleh output berupa surface elevation dan current speed. Verifikasi hasil model dengan data pasang surut pengukuran ADCP memiliki bentuk yang hampir sama, namun pada data pengukuran lapangan menunjukan pergerakan pasang surut lebih acak pada masa pasang surut perbani. Perhitungan nilai error $4.5 \%$ dan RMSE 
0.287 dari proses tersebut dapat dilihat pada gambar 10.

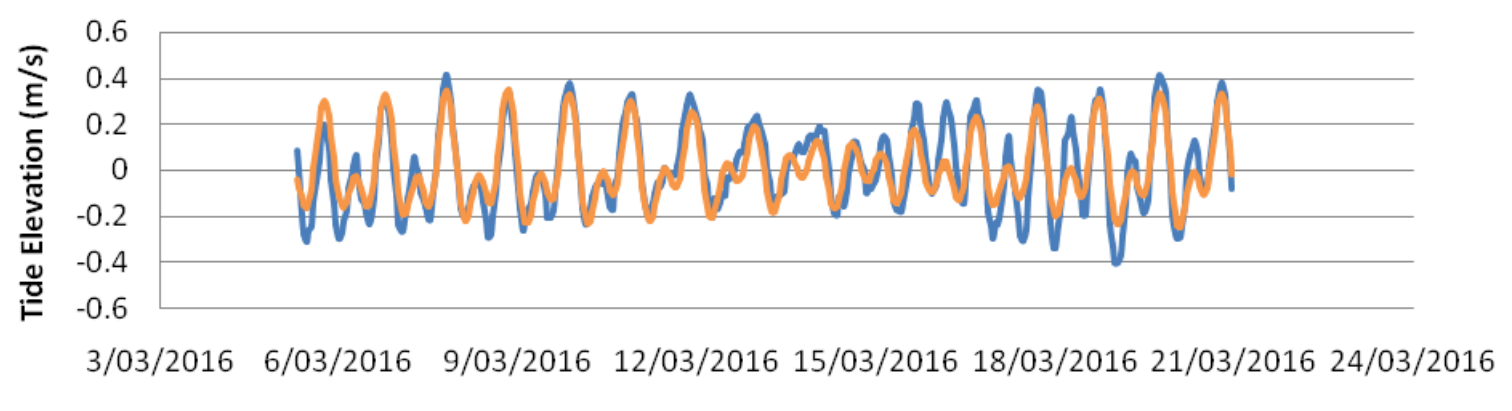

Waktu Pengukuran

-lapangan model

Gambar 10. Verifikasi hasil pemodelan dengan data pasang surut

Simulasi arus laut menuju surut purnama (gambar 11 dan gambar 12), menunjukan pola arus dominan ke Timur dan Tenggara.
Terlihat bahwa arus permukaan dipengaruhi oleh pergerakan angin.

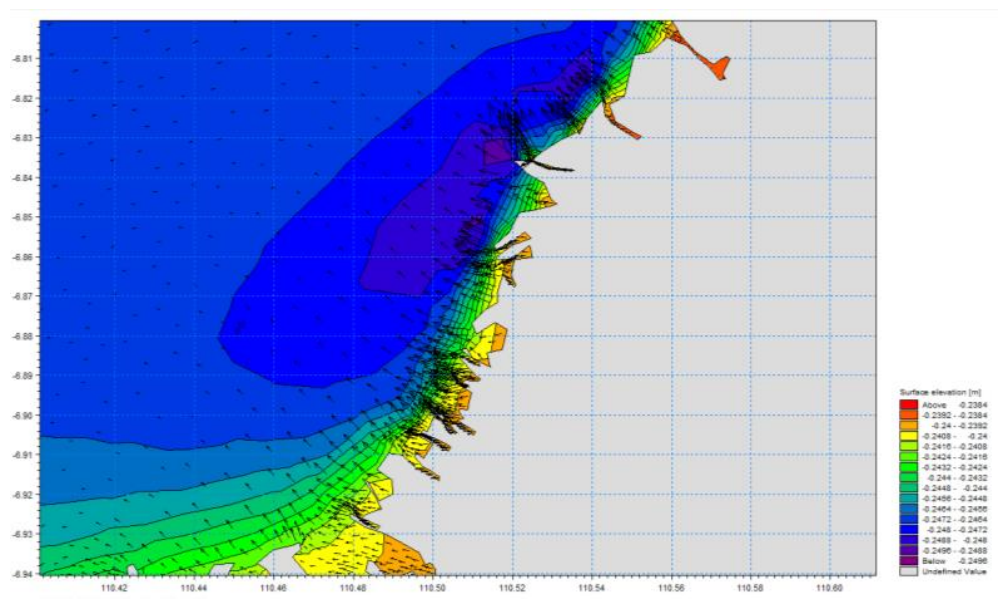

Gambar 11. Simulasi elevasi muka air saat surut purnama

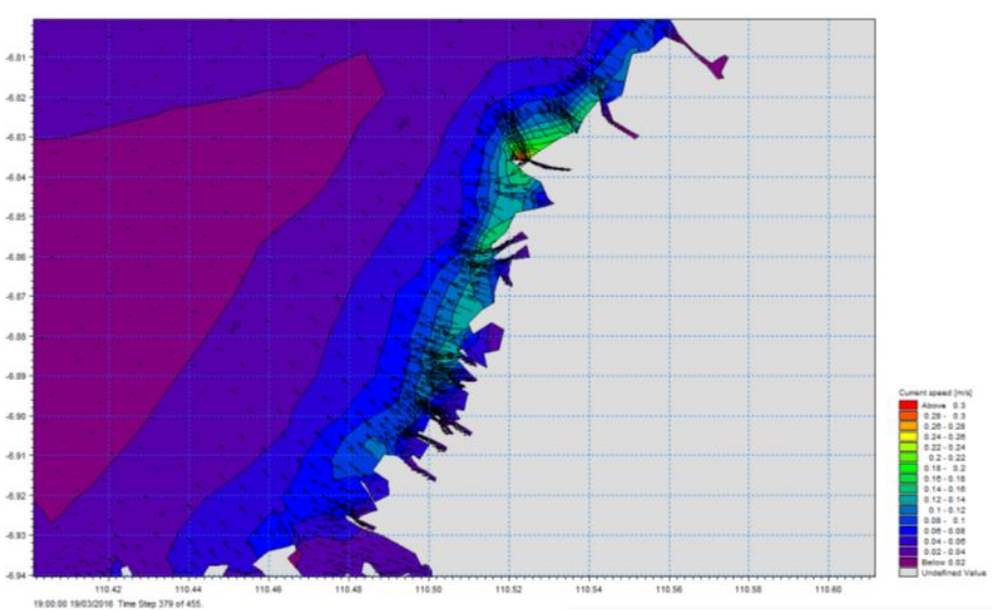

Gambar 12. Simulasi arus laut saat surut purnama 
Pada saat surut purnama, kecepatan arus berkisar antara $0-0.234 \mathrm{~m} / \mathrm{s}$. Hal ini disebabkan karena terjadinya pasang terendah sehingga energi yang dihasilkan pun relatif kecil. Pola arus laut terlihat sangat jelas menjauhi lautan, fenomena ini terjadi karena adanya pengaruh lamanya periode pasang perbani. Periode pasang surut saat perbani relative lebih lama karena berkurangnya pengaruh gaya tarik bumi bulan dan matahari. Dibandingkan pada saat pasang purnama, pengaruh gaya tarik bumi bulan dan matahari lebih kuat, sehingga pada saat bulan purnama kecepatan arus akan lebih besar.

Pada Kecamatan Sayung terdapat beberapa sungai yang bermuara pada Kecamatan Sayung tersebut, sungai-sungai membawa padatan tersuspensi dari daratan. Pada saat pasang, pergerakan massa air dari arah laut menuju ke bagian dalam sungai, massa air akan membawa padatan tersuspensi dari arah laut ke dalam sungai. Pada saat pasang, aliran massa air akan membawa padatan tersuspensi yang berasal dari laut akan tertahan oleh pergerakan massa air yang terjadi pada daerah sungai.

Pada saat bulan purnama konsentrasi sedimen terlarut akan lebih tinggi karena terjadi elevasi muka air yang lebih besar dari pada saat surut. Perbedaan elevasi permukaan akan menyebabkan pergerakan massa air dalam jumlah yang besar. Pergerakan massa air akan mempengaruhi konsentrasi sedimen yang terlarut. Hal ini sesuai dengan hasil penelitian (Sudrajat, 2014) yang menyatakan bahwa jumlah sedimen akan meningkat ketika saat surut karena sedimen yang terbawa saat pasang akan mengendap di dasar perairan.

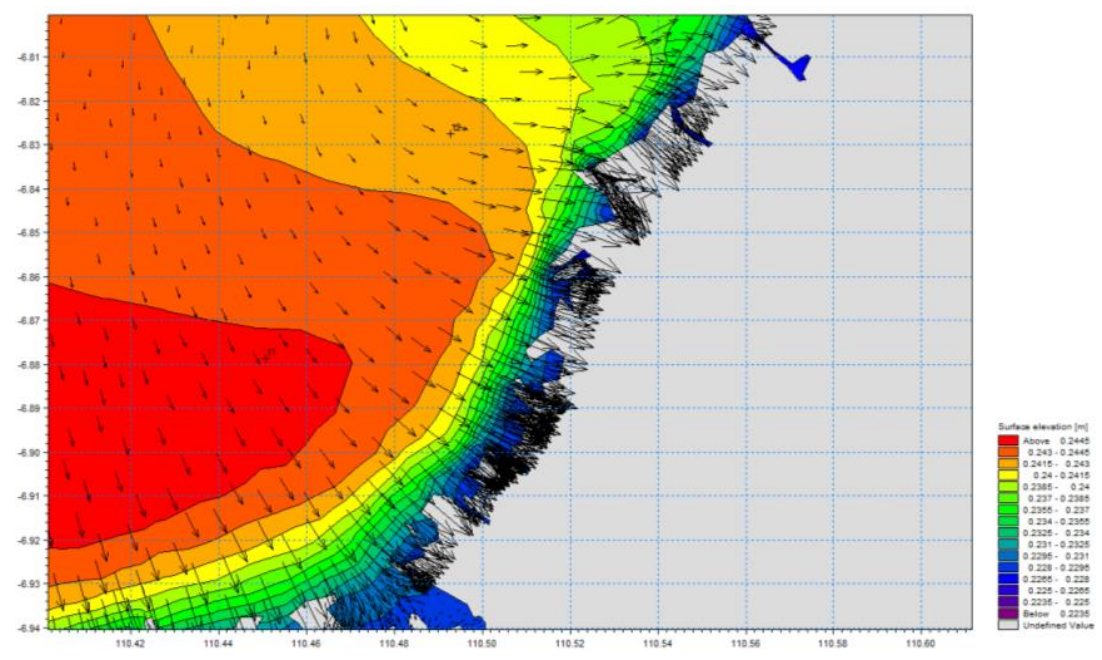

Gambar 13. Simulasi elevasi muka air saat pasang purnama

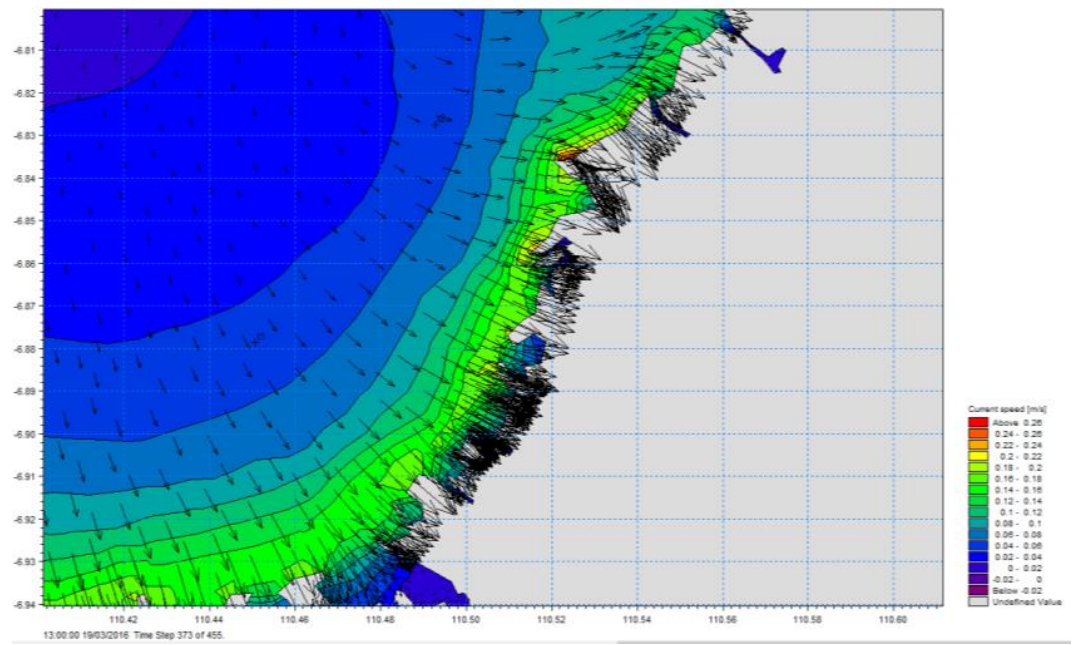

Gambar 14 Simulasi arus laut pada saat pasang purnama 
Pada saat pasang purnama, kecepatan arus relatif sedang berkisar antara $0-0.36 \mathrm{~m} / \mathrm{s}$. Hal ini disebabkan karena terjadinya pasang tertinggi sehingga energi yang dihasilkan pun relatif sedang. Pola arus laut terlihat sangat jelas mendekati daratan, fenomena ini terjadi karena adanya pengaruh lamanya periode pasang purnama. Peristiwa ini berkaitan erat dengan fenomena downwelling dan upwelling. Ketika terjadinya pasang, masa air yang bergerak ke pantai akan diteruskan menuju dasar perairan (downwelling) namun sebaliknya pada saat terjadinya surutakan terjadi fenomena upwelling, dimana massa air yang berapa di bawah permukaan akan naik ke atas mengisi kekosongan yang terjadi di area tersebut.

Hasil pemodelan Spectral Waves pada tahun 2016 menunjukkan bahwa nilai Hs pada saat pasang purnama bernilai 0,015 - 0,359 meter. Pada saat surut purnama bernilai $0,009-0,358$ meter. Tinggi gelombang pada saat pasang purnama bernilai antara 0,032 0,744 meter sedangkan pada saat surut purnama bernilai antara 0,001-0,742 meter. Hal ini menunjukkan bahwa abrasi yang terjadi di perairan Kecamatan Sayung diakibatkan oleh kikisan gelombang yang terjadi secara terus menerus dan dapat menyebabkan daerah pesisir menjadi rentan.

Pada saat surut, pergerakan massa air dari arah sungai menuju ke arah laut, massa air ini akan membawa padatan tersuspensi dari daratan menuju ke arah laut. Pethick (1984) menyebutkan bahwa sedimen pantai berasal dari tiga sumber yaitu erosi sungai, erosi dasar laut dan erosi pantai.

\section{Analisa Rob}

Data pasang surut yang digunakan untuk analisis Rob adalah data pengukuran ADCP pada bulan Maret 2016. Data hasil pengukuran tersebut kemudian diolah dengan menggunakan Mike 21. Dari hasil pengolahan tersebut dilakukan peramalan data pasang surut dengan menggunakan Mike 21. Data peramalan ini yang digunakan sebagai dasar perhitungan model genangan rob. Model genangan rob menggunakan formula yang merefleksikan perubahan MSL. Wilayah yang terkena genangan rob diketahui dengan cara memasukkan nilai kenaikan muka air laut. Sedangkan untuk input tinggi muka air laut adalah selisih antara HHWL dan MSL
Model genangan yang dibuat menggunakan asumsi bahwa selama periode nilai kenaikan muka air laut bersifat konstan. Dari data hasil pengolahan data dapat terlihat bahwa ada perbedaan yang kontras genangan yang terjadi pada saat pasang dan surut di setiap tahunnya. Kenaikan muka air laut yang terjadi setiap tahunnya berbanding terbalik dengan luas genangan yang dihasilkan. Hal ini terjadi karena dari tahun 1995-2016 juga terjadi perubahan garis pantai. Kenaikan muka air laut yang terjadi secara linier dari tahun ke tahun akan berdampak besar dengan lingkungan pesisir jika tidak dilakukan tindakan yang preventif pada proses tata kelola ruang pesisir.

\section{KESIMPULAN DAN SARAN}

Pola arus pasang surut hasil permodelan menunjukkan hasil yang kecepatan arus yang cukup kuat dan berkaitan dengan adanya fenomena upwelling dan downwelling diperairan Sayung, tinggi gelombang signifikan yang cukup tinggi dengan periode yang cukup cepat menyebabkan tingkat abrasi di perairan Sayung meningkat di tiap tahunnya, hasil dari analisis model elevasi diketahui bahwa wilayah genangan rob yang sangat luas pada tahun 2016, yang menyebabkan perubahan garis pantai dan berkurangnya wilayah daratan di Sayung, Demak.

Oleh karena itu, sangat perlu untuk segera dilakukan tindakan preventif untuk mencegah naiknya permukaan air laut ke daerah pemukiman serta pencegahan terhadap abrasi dan akresi terhadap dearah pesisir Perairan Sayung, Demak. Bentuk pencegahan yang efektif adalah dengan membangun detached struktur seperti seawall atau revetment atau kombinasi keduanya untuk mencegah erosi yang lebih besar.

\section{UCAPAN TERIMA KASIH}

Ucapan terima kasih disampaikan kepada Loka Penelitian Sumber Daya dan Kerentanan Pesisir (LPSDKP) Kementerian Kelautan dan Perikanan atas DIPA anggaran penelitian Sayung, Demak 2016 dan semua pihak yang membantu dalam pelaksanaan kegiatan penelitian ini. 


\section{DAFTAR PUSTAKA}

Arif, M., \& Laksmi, L. (2006). Analisa Kesesuaian Perairan Tambak Di Kabupaten Demak Ditinjau Dari Nilai Klorofil-A, Suhu Permukaan Peraian Dan Muatan Padatan Tersuspensi Menggunakan Data Citra Satelit Landsat ETM 7+. Jurnal Penginderaan Jauh. LAPAN

Asyiah, S., Rindarjono, M., \& Muryani, C. (2015). Analisis Perubahan Permukiman Dan Karakteristik Permukiman Kumuh Akibat Abrasi Dan Inundasi Di Pesisir Kecamatan Sayung Kabupaten Demak Tahun 2003 - 2013. Jurnal Geoeco, I. UNS

Coastal Hydrolic Laboratory (CHL). (2002). Coastal Engineering Manuals. US Army Coastal Engineering Research Center, Washington.

Desmawan, B. K. (2014). Adaptasi Masyarakat Kawasan Pesisir Terhadap Banjir Rob Di Kecamatan Sayung, Kabupaten Demak, Jawa Tengah. Jurnal Bumi Indonesia, UGM.

Diposaptono, S., Budiman, \& Firdaus, A. 2009. Menyiasati Perubahan Iklim di Wilayah Pesisir dan Pulau-Pulau Kecil. Buku IImiah Populer, Bogor, hlm. 50133.

Hakim, I., Fiqigozari, M., Pranoto, S., \& Nugroho, P. (2014). Perencanaan Perlindungan Pantai Demak. Jurnal karya Teknik Sipil. Universitas Gajah Mada

Istiqomah, S., Sasmito, B., Ammourahman, F. (2016). Pemantauan Perubahan Garis Pantai Menggunakan Aplikasi DSAS Studi Kasus: Pesisir Kabupaten Demak. Jurnal Geodesi. UNDIP

Manumono, D. (2007). Dampak Abrasi Dan ROB Terhadap Perilaku Masyarakat Kawasan Pesisir Di Kabupaten Demak. Instiper. Yogyakarta.

Peterson, O. S. (2013). Model and Modellers for Coastal Floading. Research Coastal and Estuari Engineering, DHI.

Pethick, J. (1984). An introduction to coastal geomorphology. Edward Arnold, Maryland.

Pratomoatmojo, N. A., \& Sianturi, R. S. (2011). Facing climate change: coping strategies by coastal communities in Sayung-Demak, Indonesia. CNRD Brief.

Sudradjat, C., Syahril, B. K., \& Kardhana, H. (2014). Kajian Sedimentasi Di Sekitar Muara Sungai Wanggu Kecamatan Sayung Jawa Tengah. Institut Teknologi Bandung

Triatmodjo, B. (1999). Teknik Pantai. Yogyakarta: Beta Offset.

Wibowo, Y. A. (2012). Dinamika Pantai (Abrasi dan Sedimentasi). FTIK Universitas Hang Tuah, Surabaya.

http://news.detik.com/berita/3232049/banjirrob-di-semarang-jalur-pantura-macetpanjang. Diakses pada 15 Juli 2016 